\title{
Efektivitas Model Pembelajaran Inquiry dan Problem Based Learning Terhadap Kemampuan Pemecahan Masalah pada Mata Pelajaran Matematika Kelas IV SD
}

\author{
Rika Dwi Susilowati, Wahyudi
}

(C) 2020 JEMS (Jurnal Edukasi Matematika dan Sains)

This is an open access article under the CC-BY-SA license (https://creativecommons.org/licenses/bysa/4.0/) ISSN 2337-9049 (print), ISSN 2502-4671 (online)

\begin{abstract}
Abstrak:
Tujuan penelitian ini adalah menguji perbedaan efektivitas model Inquiry dan Problem Based Learning terhadap peningkatan kemampuan pemecahan masalah pada mata pelajaran matematika kelas IV SD. Penelitian ini merupakan penelitian eksperimental semu dengan populasi sekolah dasar di Gugus Gatot Subroto Kecamatan Ungaran Timur. Teknik pengambilan sampel dengan probabily sampling jenis cluster sampling. Sampel penelitian adalah siswa kelas IV SD Negeri Beji 02 sebagai kelas eksperimen dan SD Negeri Beji 01 sebagai kelas kontrol. Teknik pengumpulan data penelitian melalui observasi dan soal tes uraian. Desain penelitian ini adalah Nonequivalent Control Group Design. Teknik analisis data dilakukan dengan uji normalitas Saphiro-Wilk dan uji homogenitas untuk mengetahui perbedaan digunakan statistik parametrik uji T-Test (Independent Samples T-test) dan uji efektivitas dengan Normalized Gain (N-Gain). Hasil penelitian menunjukkan bahwa nilai sig. (2-tailed) pada uji t-test sebesar 0,000 $<0,05$ sehingga Ha diterima. Tingkat keefektifan dihitung dengan analisis N-Gain pada model Problem Based Learning sebesar 48,9681\% termasuk kategori kurang efektif, sedangkan pada model pembelajaran Inquiry sebesar 38,9476\% termasuk kategori tidak efektif. Dari penelitian ini dapat disimpulkan bahwa terdapat perbedaan efektivitas dalam penerapan model Inquiry dan Problem Based Learning terhadap peningkatan kemampuan pemecahan masalah. Dengan tingkat efektivitas model pembelajaran Problem Based Learning lebih tinggi dari model pembelajaran Inquiry.
\end{abstract}

Kata Kunci: Inquiry; Problem Based Learning; Kemampuan Pemecahan Masalah

\begin{abstract}
:
This research aims at analyzing the difference of effectiveness from the implementation of Inquiry Model and Problem-Based Learning Model on the improvement of IV Graders' problem solving ability in Mathematic subject. This is a quasi-experimental research with the population of elementary school children in Gugus Gatot Subroto Kecamatan Ungaran Timur. The sample were collected using probability sampling, particularly cluster sampling. The sample were IV grade students of SD Negeri Beji 02 as the experiment class, while the IV grade students of SD Negeri Beji 01 were selected as the control class. This research used Nonequivalent Control Group Design. The acquired data were analyzed using Saphiro-Wilk normality test and homogeneity test. To analyze the differences, statistic parametric T-Test (Independent Samples T-test) was selected. And finally, the effectiveness test was conducted using Normalized Gain (NGain). The findings presented that the value of sig. (2-tailed) in the t-test was $0,000<0,05$ that made $\mathrm{Ha}$ accepted. The effectiveness rate calculated from N-Gain analysis in ProblemBased Learning Model was $48.9681 \%$ and considered to be less effective, while the effectiveness rate gained from Inquiry Learning was $38.9476 \%$ and classified as not effective. Hence, it can be concluded that there is a difference on the effectiveness in implementing Inquiry model and Problem Based Learning Model on the improvement of students' problem solving ability. In regards to this matter, the effectiveness of Problem Based Learning is higher than Inquiry Learning model.
\end{abstract}

Keywords: Inquiry; Problem Based Learning; Problem Solving Ability

Rika Dwi Susilowati, Universitas Kristen Satya Wacana

rikadwi614@gmail.com

Wahyudi, Universitas Kristen Satya Wacana

yudhi@staff.uksw.edu

\section{Pendahuluan}


Pembelajaran merupakan interaksi antara guru dan siswa yang dilaksanakan dalam proses pendidikan guna mencapai tujuan tertentu sesuai dengan kurikulum. Kurikulum merupakan seperangkat rencana dan pengaturan mengenai tujuan, isi, dan bahan pelajaran

serta cara yang digunakan sebagai pedoman penyelenggaraan kegiatan pembelajaran. Pendidikan berdasarkan tuntutan abad 21 menimbulkan paradigma perkembangan penyelenggaraan pendidikan dengan menekankan kemampuan siswa dalam mencari tahu dari berbagai sumber, merumuskan permasalahan, berpikir analitis, dan kerja sama serta berkolaborasi dalam menyelesaikan masalah (Litbang Kemendikbud, 2013). Diberlakukannya Kurikulum 2013 sebagai pedoman penyelenggaraan pembelajaran, merubah cara belajar siswa melalui lingkungan tempat tinggal beserta permasalahan di dalamnya. Selain itu, untuk memberikan kebermaknaan bagi siswa, penyelenggaraan pembelajaran menekankan beberapa unsur meliputi; gerakan literasi, penguatan pendidikan karakter, kemampuan berpikir tingkat tinggi/ HOTS (Higher Order Thinking Skills), serta 4C (communication, collaborative, critical thinking, and creativity).

Tujuan sesuai tuntutan kurikulum dapat direalisasikan dengan cara guru harus mampu mendesain pembelajaran sesuai dengan Standar Proses dalam Permendikbud Nomor 22 Tahun 2016 bahwa proses pembelajaran pada satuan pendidikan diselenggarakan secara interaktif, inspiratif, menyenangkan, menantang, memotivasi siswa untuk berpartisipasi aktif, serta memberikan ruang yang cukup bagi prakarsa, kreativitas, dan kemandirian sesuai dengan bakat, minat, dan perkembangan fisik serta psikologis siswa. Penyelenggaraan proses pembelajaran yang demikian, dapat diwujudkan melalui pembelajaran yang dikaitkan pada pengalaman siswa dalam kehidupan sehari-hari dengan harapan siswa dapat menyelesaikan masalah yang sama pada kehidupannya kelak. Upaya yang dapat dilakukan guru adalah membelajarkan siswa sesuai dengan gaya belajar seusianya dan didukung dengan adanya berbagai model pembelajaran. Berdasarkan tuntutan kurikulum 2013 sangat disarankan penerapan pembelajaran menggunakan 3 model yaitu: (1) model pembelajaran berbasis penyingkapan/ penelitian (discovery learning / inquiry); (2) model pembelajaran berbasis masalah (problem based learning); (3) model pembelajaran berbasis projek (project based learning).

Model pembelajaran Inquiry dan Problem Based Learning sebagai model yang dipilih, memiliki kesamaan yaitu digunakan untuk pembelajaran bersifat kontekstual dan berbasis masalah, sehingga kedua model sangat cocok apabila digunakan dalam kurikulum 2013 terutama pada anak di tingkat sekolah dasar. Model pembelajaran Inquiry adalah rangkaian kegiatan belajar yang menekankan pada proses berfikir secara kritis dan analitis untuk mencari dan menemukan sendiri jawaban dari suatu masalah yang dipertanyakan (Daryanto, 2017). Sedangkan model pembelajaran Problem Based Learning merupakan rangkaian kegiatan yang melibatkan siswa dalam pemecahan masalah dengan mengintegrasikan berbagai konsep dan keterampilan berbagai disiplin ilmu (Bern dan Erickson dalam Komalasari, 2011).

Sintagmatik pada kedua model mengandung unsur kegiatan ilmiah yang hampir sama. Pada model pembelajaran Inquiry memiliki sintagmatik pembelajaran yang meliputi: (1) merumuskan masalah; (2) membuat hipotesis; (3) merancang percobaan; (4) melaksanakan percobaan untuk memperoleh informasi; (5) mengumpulkan dan menganalisis data; (6) membuat kesimpulan (Trianto, 2009). Sedangkan model Problem Based Learning memiliki sintagmatik sebagai berikut : (1) orientasi siswa pada masalah; (2) mengorganisasikan siswa untuk belajar; (3) membimbing penyelidikan individu maupun kelompok; (4) mengembangkan dan menyajikan hasil karya; (5) menganalisis dan mengevaluasi proses pemecahan masalah (Arends, 2012) , namun langkah kegiatan pembelajaran pada kedua model memiliki perbedaan 
yaitu pada langkah kegiatan pembelajaran dengan model Inquiry siswa dimulai dengan memahami masalah dan membuat jawaban sementara. Sedangkan pada pembelajaran Problem Based Learning sebelum siswa memahami permasalahan, guru memberikan materi terlebih dahulu sebagai bekal selama proses pembelajaran dengan langkah pemecahan masalah.

Menurut Polya (dalam Wahyudi \& Anugraheni, 2017) terdapat empat aspek pemecahan masalah yaitu; memahami masalah, merencanakan penyelesaian, melakukan penyelesaian, dan mengecek kembali jawaban. Matematika sebagai salah satu muatan pelajaran yang didalamnya terdapat masalah pada kehidupan sehari-hari memerlukan penyelesaian yang dilakukan secara sistematis dan bermakna agar siswa dapat mengatasi masalah yang sama di kemudian hari (Komalasari, 2011). Masalah matematika biasa disajikan dalam bentuk soal cerita yang berkaitan dengan kehidupan sehari-hari, namun sebagian besar guru masih menggunakan metode menghafal rumus (teacher centered) dan tidak melibatkan siswa dalam rangkaian kegiatan pemecahan masalah yang dilakukan secara bertahap. Hal ini menyebabkan kemampuan pemecahan masalah siswa menjadi rendah dan siswa mengalami kesulitan mengerjakan soal dalam bentuk cerita, terlebih apabila langkah pengerjaan soal tidak sesuai (Maarif \& Wahyudi, 2015). Selain itu, kesulitan yang dialami oleh siswa pada umumnya terkait pada kurangnya minat siswa dalam membaca dan memahami topik matematika secara teoritis karena model pembelajaran yang kurang menarik perhatian siswa dengan kemungkinan yang terjadi siswa sudah menyerah dahulu saat mendapatkan soal matematika sehingga siswa beranggapan pelajaran matematika adalah sulit.

Matematika merupakan muatan pelajaran yang sangat dibutuhkan selama kehidupan itu berlangsung, sehingga pelajaran matematika harus diberikan sejak sedini mungkin yaitu pada tingkat pendidikan dasar untuk menyiapkan kehidupan yang akan datang. Seperti yang tertuang dalam Permendikbud No. 21 Tahun 2016 tentang Standar Isi, pembelajaran matematika pada pendidikan dasar diharapkan dapat mengembangkan kompetensi siswa berpikir logis, cermat, jujur, bertanggung jawab dan tidak mudah menyerah dalam penyelesaikan masalah. Pada jenjang Sekolah Dasar kompetensi tersebut dapat diwujudkan dengan melatih kemampuan mengubah bahasa verbal ke dalam model matematis dalam bentuk soal cerita, dimana soal cerita merupakan perumpamaan masalah dalam kehidupan nyata yang dihadapi. Sejalan dengan pendapat dari Bruner (dalam Karso dkk, 2014) yang menyatakan bahwa dalam proses matematika terdapat 3 tahap, yaitu pada tahap pertama pembelajaran dimulai dengan konsep atau fakta yang bersifat abstrak yang diawali dari kehidupan sehari-hari yang dapat diwujudkan dalam bentuk soal cerita. Tahap kedua siswa dapat membentuk bayangan dari benda atau peristiwa keseharian. Tahap ketiga siswa dapat mengenal simbol-simbol bersifat abstrak sebagai wujud bahasa matematika.

Penelitian dengan model yang sama telah dilakukan oleh beberapa peneliti seperti Nadhifah \& Afriansyah (2016), dengan sampel siswa kelas VIII SMP menyatakan bahwa tidak terdapat perbedaan pada kemampuan pemecahan masalah matematis antara siswa yang mendapatkan pembelajaran Problem Based Learning ataupun Inquiry dan peningkatan kemampuan pemecahan masalah menggunakan kedua model tergolong tinggi. Lain halnya dengan Indarwati, dkk (2014) menyatakan bahwa penerapan model Problem Based Learning dapat meningkatkan kemampuan pemecahan masalah matematika siswa kelas VIII SMP dan Astuti, dkk (2018) menyatakan bahwa model pembelajaran Problem Based Learning berpengaruh terhadap kemampuan pemecahan masalah matematika siswa kelas IV SD. Beberapa penelitian menunjukan bahwa model Problem Based Learning lebih efektif digunakan dalam pemecahan masalah, namun materi pemecahan masalah yang digunakan berbeda dengan peneliti seperti 
bilangan pecahan. Terdapat pula penelitian yang mengatakan bahwa tidak terdapat berbedaan pada penerapan kedua model pada materi bangun kubus dan balok. Selain itu dari beberapa penelitian dengan model yang sama menggunakan sampel siswa tingkat SMP. Sehingga dari hasil analisis yang dilakukan, memunculkan keraguan apakah terdapat perbedaan efektivitas penerapan model pembelajaran Inquiry dan Problem Based Learning terhadap peningkatan kemampuan pemecahan masalah matematika siswa kelas IV SD terutama pada materi keliling dan luas bangun datar.

\section{Metode}

Penelitian ini merupakan penelitian eksperimental semu karena dilakukan untuk mencari pengaruh perlakuan tertentu terhadap suatu variabel dengan adanya manipulasi objek penelitian serta kelas kontrol (Slameto, 2012; Sugiyono, 2012). Penelitian ini menggunakan dua variabel yaitu variabel terikat berupa kemampuan pemecahan masalah matematika dan variabel kontrol berupa model pembelajaran Inquiry dan Problem Based Learning. Penelitian ini menggunakan teknik pengambilan sampel probabily sampling jenis cluster sampling. Populasi pada penelitian ini adalah siswa kelas IV yang berada di gugus Gatot Subroto, Kecamatan Ungaran Timur. Sebagai sampel penelitian adalah siswa kelas IV SD Negeri Beji 01 sebagai kelas kontrol dan siswa kelas IV SD Negeri Beji 02 sebagai kelas eksperimen. Penelitian ini dimulai pada bulan Januari Februari 2020. Penelitian dilakukan dengan memberikan perlakuan yang berbeda pada siswa dengan model pembelajaran Problem Based Learning pada kelas eksperimen dan Inquiry pada kelas kontrol.

Teknik pengumpulan data penelitian melalui observasi dengan bantuan lembar observasi kegiatan guru dan siswa dan teknik tes dengan beberapa soal uraian. Pada instrument tes kognitif tingkat validitas soal dapat diukur dengan mengacu pada nilai $r$ Product Moment dengan taraf signifikansi 5\% dengan jumlah siswa 31 sebesar 0,355. Dari hasil pengukuran menggunakan program SPSS 20.00 for windows menunjukan bahwa 10 soal yang digunakan adalah valid karena memiliki nilai rhitung > rtabel. Tingkat keajegan atau reliabilitas mengacu pada rentang indeks reliabilitas dalam Tabel 1.

Tabel 1. Indeks dan Kriteria Penentuan Tingkat Reliabilitas (Wardani, 2012)

\begin{tabular}{cc}
\hline Indeks & Kriteria \\
\hline $0,81-1,00$ & Sangat tinggi \\
$0,61-0,80$ & Tinggi \\
$0,41-0,60$ & Cukup \\
$0,21-0,40$ & Rendah \\
$0,00-0,20$ & Sangat rendah \\
\hline
\end{tabular}

Hasil dari uji reliabilitas soal dengan menggunakan SPSS 20, menunjukkan bahwa nilai cronbach's alpha yang dihasilkan sebesar 0,946 dan terletak pada rentang indeks 0,81 - 1,00 sehingga dapat disimpulkan bahwa soal kemampuan pemecahan masalah sangat reliabel.

Desain penelitian eksperimen yang digunakan adalah Nonequivalent Control Group Design. Tahap awal sebelum diberikan perlakuan dengan model pembelajaran, dilakukan pretes untuk mengukur kemampuan awal, baik pada kelas kontrol maupun kelas eksperimen. Langkah selanjutnya adalah memberikan perlakuan yang berbeda diantara dua kelas sampel yaitu pada kelas eksperimen digunakan model pembelajaran Problem Based Learning dalam proses pemecahan masalah dan pada kelas kontrol digunakan model pembelajaran Inquiry. 
Ketercapaian proses pembelajaran dianalisis dengan melihat persentase keterlaksanaan sintaks pada masing-masing model dengan rumus: $\frac{\text { jumlah skor yang diperoleh }}{\text { skor maksimal }} \times 100 \%$.

Selanjutnya, pada tahap akhir penelitian diadakan postes atau pengukuran akhir untuk melihat apakah ada perbedaan yang signifikan antara sebelum menerapkan model pembelajaran dan setelah menerapkan model pembelajaran dengan melihat selisih antara pretes dan postes baik pada kelas kontrol maupun kelas eksperimen. Desain penelitian dapat digambarkan pada tabel 2.

Tabel 2. Desain Penelitian Nonequivalent Control Group Design (Sugiyono, 2012)

\begin{tabular}{cccc}
\hline Kelas & Pretes & $\begin{array}{c}\text { Variabel Bebas/ } \\
\text { Perlakuan }\end{array}$ & Postes \\
\hline $\begin{array}{c}\text { Kelompok } \\
\begin{array}{c}\text { Eksperimen } \\
\text { Kelompok } \\
\text { Kontrol }\end{array}\end{array}$ & $\mathrm{O}_{1}$ & $\mathrm{X}_{1}$ & $\mathrm{O}_{2}$ \\
\hline
\end{tabular}

Berdasarkan desain penelitian Nonequivalent Control Group Design yang dipilih maka efektivitas kedua model tidak dapat dilihat dari hasil postes saja, sehingga untuk melihat perbandingan efektivitas kedua model digunakan analisis Normalized Gain (N-Gain). Gain yang dinormalisasikan (N-Gain) dapat dihitung dengan persamaan berikut (Hake, 1998):

Keterangan:

$$
<\mathrm{g}>=\frac{\text { Sposttest }- \text { Spretest }}{\text { Smax }- \text { Spretest }}
$$

g : : Gain yang dinormalisasi (N-gain) dari kedua model

$\mathrm{S}_{\max } \quad$ :Skor maksimum (ideal) dari tes awal dan tes akhir

$S_{\text {posttest }}:$ Skor tes akhir

Spretest : Skor tes awal

Tingkat keefektifan model pembelajaran Inquiry dan Problem Base Learning digunakan dengan melihat nilai rata-rata pada nilai N-Gain Persen pada uji normalitas.

Teknik analisis data dilakukan dengan uji statistik deskriptif untuk mengetahui selisih ratarata, nilai minimal, nilai maksimal, dan standar deviasi dari hasil tes. Setelah mengetahui perbedaan peningkatan rata-rata dilakukan uji prasyarat dengan uji normalitas Saphiro-Wilk dan uji homogenitas berbantuan SPSS 20. Apabila kedua uji prasyarat menunjukan hasil normal dan homogen maka dilakukan uji statistik parametrik untuk menentukan ada tidaknya perbedaan tingkat efektivitas penerapan model Inquiry dan Problem Base Learning terhadap kemampuan pemecahan masalah matematika, apabila menunjukan hasil yang tidak normal maka dilakukan uji non-parametrik. Tingkat keefektifan penerapan kedua model, dapat dilihat dengan melakukan analisis Normalized Gain (N-Gain) berbantuan SPSS 20 dengan berpedoman pada tabel 3 .

Tabel 3. Kategori Efektivitas N-Gain ( Hake, 1999) 


\begin{tabular}{cc}
\hline Persentase (\%) & Tafsiran \\
\hline$<40$ & Tidak efektif \\
$40-55$ & Kurang efektif \\
$56-75$ & Cukup efektif \\
$>76$ & Efektif \\
\hline
\end{tabular}

\section{Hasil dan Pembahasan}

\section{Hasil}

\section{Analisis Proses Pembelajaran}

Persentase keterlaksanaan proses pembelajaran pada kelas eksperimen dengan model Problem Based Learning sebesar 93\% lebih kecil dari model Inquiry dengan persentase sebesar 95,6\% dikarenakan terdapat beberapa kegiatan pendahuluan pada kelas eksperimen yang belum terlaksana. Meskipun langkah-langkah pada kedua model terlaksana dengan baik, namun respon yang diberikan siswa pada masing-masing model berbeda. Pada kelas eksperimen siswa dalam kelompok lebih aktif dalam mengikuti pembelajaran dan berusaha untuk lebih unggul dari kelompok lain, sedangkan pada kelas kontrol siswa lebih pasif sehingga guru memberikan perlakuan lebih untuk memacu siswa untuk aktif.

\section{Analisis Hasil Belajar}

Tabel 4. Komparasi Hasil Pengukuran Kemampuan Pemecahan Masalah

\begin{tabular}{cccc}
\hline \multirow{2}{*}{ Pengukuran } & \multicolumn{2}{c}{ Rata-rata Skor (Mean) } & \multirow{2}{*}{ Selisih } \\
\cline { 2 - 3 } & Pretes & Postes & \\
\hline Eksperimen & 49,78 & 75,66 & 11,02 \\
\hline Kontrol & 60,80 & 76,60 & 0,06 \\
\hline
\end{tabular}

Dari data hasil komparasi rata-rata di tabel 4, telihat bahwa selisih rata-rata skor pretes dan postes dengan model pembelajaran Problem Based Learning adalah 11,02. Sedangkan selisih rata-rata skor pretes dan postes dengan model pembelajaran Inquiry adalah 0,06. Diagram komparasi data antara kedua kelas dapat dilihat pada gambar diagram 1. 


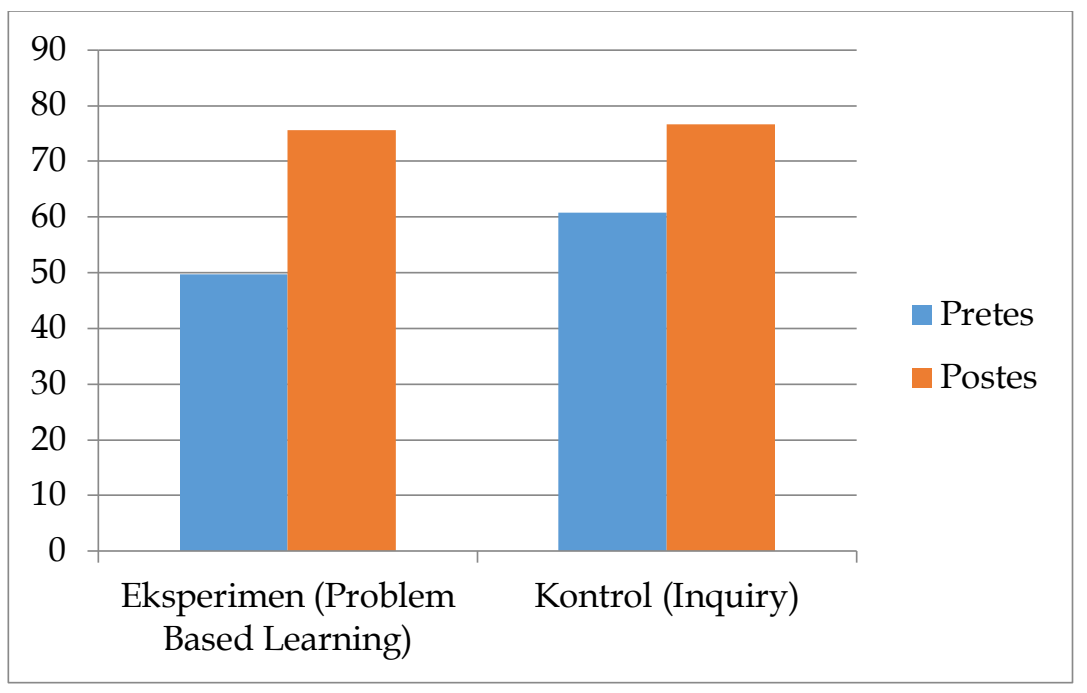

Gambar 1. Diagram Komparasi Nilai Rata-rata

Berdasarkan diagram 1 dapat dilihat bahwa hasil tes kemampuan pemecahan masalah baik pada model pembelajaran Inquiry dan model pembelajaran Problem Based Learning mengalami kenaikan. Kenaikan yang lebih signifikan terlihat pada kelas eksperimen dengan model pembelajaran Problem

Based Learning. Setelah diketahui adanya perbedaan rata-rata hasil tes pemecahan masalah, untuk menentukan teknik analisis data maka dilakukan uji normalitas terhadap hasil pretes dan postes pada kelas eksperimen dan kontrol. Hasil uji normalitas dapat dilihat pada tabel 5.

Tabel 5. Hasil Uji Normalitas

\begin{tabular}{clcccc}
\hline \multicolumn{2}{c}{ Pretes dan Postes } & \multicolumn{3}{c}{ Saphiro- Wilk } & \multicolumn{1}{c}{ Kategori } \\
\cline { 2 - 5 } Hasil Belajar Siswa & Statistics & Df & Sig. & \\
& $\begin{array}{l}\text { Pretes Eksprerimen } \\
\text { (PBL) }\end{array}$ & .960 & 32 & .543 & $\begin{array}{l}\text { Berdistribusi } \\
\text { normal }\end{array}$ \\
$\begin{array}{l}\text { Postes Eksperimen } \\
\text { (PBL) }\end{array}$ & .977 & 32 & .892 & $\begin{array}{l}\text { Berdistribusi } \\
\text { normal } \\
\text { Pretes Kontrol }\end{array}$ \\
$\begin{array}{l}\text { (Inquiry) } \\
\text { Postes Kontrol } \\
\text { Inquiry) }\end{array}$ & .965 & 20 & .653 & $\begin{array}{l}\text { Berdistribusi } \\
\text { normal }\end{array}$ \\
& .944 & 20 & .289 & $\begin{array}{l}\text { Berdistribusi } \\
\text { normal }\end{array}$ \\
\hline
\end{tabular}

Dari uji normalitas dengan Saphiro-Wilk diperoleh hasil uji normalitas dengan tingkat signifikansi $>0,05$. Selain uji normalitas, uji homogenitas juga diperlukan untuk menentukan jenis analisis data. Hasil uji homogenitas dapat dilihat pada tabel 6.

Tabel 6. Hasil Uji Homogenitas Pretes dan Postes

\begin{tabular}{lccccc}
\hline \multicolumn{1}{c}{ Jenis } & Lavense Statistic & df1 & df2 & Sig. & Kategori \\
\hline $\begin{array}{l}\text { Pretes Kelas Eksperimen dan } \\
\text { Kelas Kontrol }\end{array}$ & .000 & 1 & 50 & .996 & Homogen \\
$\begin{array}{l}\text { Postes Kelas Eksperimen dan } \\
\text { Kelas Kontrol }\end{array}$ & .155 & 1 & 50 & .696 & Homogen \\
\hline
\end{tabular}


Dari tabel 6 dapat dilihat uji homogenitas hasil pretes diketahui nilai Signifikansi (Sig.) adalah 0,996 >0,05, sehingga varians data pretes kelas eksperimen dan kelas kontrol adalah sama atau homogen. Begitu pula pada uji homogenitas hasil postes diketahui nilai signifikansi (Sig.) adalah 0,696 > 0,05, sehingga varians data postes adalah sama atau homogen. Dari kedua uji prasyarat diperoleh data yang digunakan berdistribusi normal dan homogen, sehingga pengolahan data dilakukan uji statistik parametrik dengan uji Independent Samples Tests untuk mengetahui ada tidaknya perbedaan efektivitas kedua model. Hasil uji T-test dapat dilihat pada tabel 7.

Tabel 7 . Hasil Uji Parametrik (Independent Samples Tests)

\begin{tabular}{|c|c|c|c|c|c|c|c|c|c|}
\hline & & \multicolumn{2}{|c|}{$\begin{array}{l}\text { Lavene's Test } \\
\text { for Equality } \\
\text { of Variances }\end{array}$} & \multicolumn{6}{|c|}{ t-test for Equality of Means } \\
\hline & & \multirow[t]{2}{*}{$\mathrm{F}$} & \multirow[t]{2}{*}{ Sig. } & \multirow[t]{2}{*}{$\mathrm{T}$} & \multirow[t]{2}{*}{ Df } & \multirow[t]{2}{*}{$\begin{array}{l}\text { Sig.(2- } \\
\text { tailed) }\end{array}$} & \multirow[t]{2}{*}{$\begin{array}{c}\text { Mean } \\
\text { Differenc } \\
\mathrm{e}\end{array}$} & \multicolumn{2}{|c|}{$\begin{array}{l}\text { 95\% Confidence } \\
\text { Interval of the } \\
\text { Difference }\end{array}$} \\
\hline & & & & & & & & Lower & Uppel \\
\hline $\begin{array}{l}\text { Hasil } \\
\text { Belajar }\end{array}$ & $\begin{array}{l}\text { Equal variances } \\
\text { assumed }\end{array}$ & 1.917 & .172 & -5.401 & 50 & .000 & 4.123 & -30.551 & -13.987 \\
\hline Siswa & $\begin{array}{l}\text { Equal variances } \\
\text { not assumed }\end{array}$ & & & -5.731 & 47.618 & .000 & 3.886 & -30.083 & -14.455 \\
\hline
\end{tabular}

Berdasarkan hasil uji Independent Samples Test dengan data yang homogen diperoleh nilai equal variances nilai Sig. (2-tailed) sebesar 0,000<0,05, maka diperoleh perbedaan rata-rata yang signifikan pada hasil belajar dengan kedua model. Sehingga disimpulkan bahwa $\mathrm{H}_{0}$ ditolak dan Ha diterima, dan rumusan masalah terjawab bahwa terdapat perbedaan efektivitas penerapan model Inquiry dan Problem Based Learning terhadap kemampuan pemecahan masalah pada mata pelajaran matematika siswa kelas IV SD. Selanjutnya untuk mengetahui perbedaan efektivitas kedua model maka dilakukan analisis N-Gain Persen seperti pada tabel 8.

Tabel 8. Hasil Analisis N-Gain Persen

\begin{tabular}{llcccc}
\hline \multicolumn{2}{c}{ Model Pembelajaran } & N & Mean & Std.Deviation & $\begin{array}{c}\text { Std. Error } \\
\text { Mean }\end{array}$ \\
\hline N-Gain Persen & $\begin{array}{l}\text { Kelas Eksperimen } \\
\text { (PBL) }\end{array}$ & 32 & 48.9681 & 31.06040 & 5.49076 \\
& Kelas Kontrol (Inquiry) & 20 & 38.9476 & 24.18034 & 5.40689 \\
\hline
\end{tabular}

Berdasarkan hasil analisis N-Gain Persen pada tabel 8, diperoleh rata-rata pada keuda kelas. Dengan berpedoman pada tabel 3 tentang kategori efektivitas N-Gain Persen diketahui kelas eksperimen dengan model pembelajaran Problem Based Learning sebesar 48,9681\% dan termasuk ke dalam kategori kurang efektif untuk meningkatkan kemampuan pemecahan matematika pada siswa kelas IV SD, sedangkan pada kelas kontrol dengan model pembelajaran Inquiry diperoleh rata-rata sebesar 38,9476\% dan termasuk ke dalam kategori tidak efektif untuk meningkatkan kemampuan pemecahan matematika pada siswa kelas IV SD. Dengan demikian dapat disimpulkan bahwa model pembelajaran Problem Based Learning lebih efektif digunakan dalam pemecahan masalah matematika pada siswa kelas IV SD dibandingkan dengan model pembelajaran Inquiry. 


\section{Pembahasan}

Berdasarkan hasil penelitian menunjukkan bahwa terdapat perbedaan efektivitas model pembelajaran Problem Based Learning dan Inquiry terhadap kemampuan pemecahan masalah matematika pada siswa kelas IV SD. Melihat tingkat keefektifan nilai rata-rata kedua model menunjukan bahwa model pembelajaran Problem Based Learning lebih efektif digunakan untuk meningkatkan kemampuan pemecahan masalah dibanding dengan model Inquiry. Hal ini bertolakan dengan hasil penelitian yang dilakukan oleh Nadhifah \& Afriansyah (2016), dengan sampel siswa kelas VIII SMP menyatakan bahwa tidak terdapat perbedaan pada kemampuan pemecahan masalah matematis antara siswa yang mendapatkan pembelajaran Problem Based Learning ataupun Inquiry. Peningkatan kemampuan pemecahan masalah pada kedua model tergolong tinggi. Berbeda dengan hasil penelitian ini, diperoleh perbedaan peningkatan kemampuan pemecahan masalah antara model pembelajaran Inquiry dan Problem Based Learning. Perbedaan tersebut disebabkan karena kelas sampel yang digunakan, pada penelitian oleh Nadhifah \& Afriansyah (2016) menggunakan sampel siswa kelas VIII SMP dengan hasil pengerjaan pretes dan postes yang tinggi karena beberapa siswa mengikuti bimbingan belajar. Selain itu, siswa VIII SMP tingkat belajar yang lebih mudah dalam menemukan pengetahuan dengan sendiri dan, sedangkan pada penelitian ini menggunakan sampel siswa kelas IV SD yang dalam pelaksanaannya bergantung pada peran guru dalam pembelajaran dan hasil pretes dan postes yang memiliki perbedaan cukup tinggi.

Perbedaan peningkatan kemampuan masalah ini juga disebabkan pada proses pembelajaran yang dilakukan dengan model Problem Based Learning, siswa lebih cepat dalam memahami permasalahan yang dihadapi, karena pada awal kegiatan pembelajaran guru terlebih dahulu memberikan materi penghantar tentang konsep bangun datar beserta cara mencari keliling dan luas bangun sebagai bekal selama kegiatan pembelajaran berlangsung. Oleh karena itu, saat diberikan masalah siswa dengan mudah memahami permasalahan dan melakuakan penyelesaian dengan konsep yang telah diajarkan sebelumnya. Hal ini sesuai dengan Ariyana (2018) bahwa tujuan pembelajaran berbasis masalah adalah meningkatkan kemampuan penerapan konsep pada permasalahan nyata. Dengan demikian tujuan pembelajaran berbasais masalah dapat tercapai dengan model Problem Based Learning. Berbeda dengan proses pembelajaran dengan model Inquiry, siswa terlebih dahulu dihadapkan pada suatu permasalahan untuk dipahami dan memberikan jawaban sementara sebelum mengetahui konsep yang digunakan dalam menyelesaikan permasalahan tersebut. Sehingga dalam proses pemecahan masalah siswa merasa takut dengan jawaban awal yang diberikan berbeda dengan jawaban setelah mereka mendapatkan konsep pada langkah penyelesaiannya. Penggunaan desain penelitian Nonequivalent Control Group Design, menjadadikan peneliti tidak mengetahui kondisi awal siswa dari kedua kelas, sehingga dengan penentuan kelas tersebut, banyak kemungkinan yang terjadi selama pembelajaran seperti, proses pembelajaran dengan model pembelajaran Inquiry yang ternyata kurang sesuai dengan kondisi kelas kontrol dengan karakter siswa di SD Negeri Beji 01.

Kebenaran hasil penelitian ini didukung pula dengan adanya peningkatan rata-rata hasil pretes dan postes yang lebih signifikan pada kelas eksperimen dengan model pembelajaran Problem Based Learning. Hal ini menguatkan penelitian yang dilakukan oleh Indarwati, dkk (2014), bahwa penerapan model Problem Based Learning dapat meningkatkan kemampuan pemecahan masalah matematika dan penelitian yang dilakukan oleh Astuti, dkk (2018), dengan hasil model 
pembelajaran Problem Based Learning berpengaruh terhadap kemampuan pemecahan masalah matematika siswa kelas IV SD.

\section{Simpulan}

Simpulan Berdasarkan hasil penelitian dan pembahasan dapat disimpulkan bahwa terdapat perbedaan efektivitas dalam penerapan model Inquiry dan Problem Based Learning terhadap peningkatan kemampuan pemecahan masalah matematika siswa kelas IV SD. Dengan tingkat efektivitas model pembelajaran Problem Based Learning yang lebih tinggi dari model pembelajaran Inquiry. Hal ini didukung dengan nilai sig. (2-tailed) pada uji t-test sebesar 0,000< probabilitas 0,05 sehingga Ha diterima. Sedangkan, tingkat keefektifan yang dihitung dengan analisis N-Gain pada model Problem Based Learning sebesar 48,9681 \% termasuk ke dalam kategori kurang efektif, sedangkan pada kelas kontrol dengan model pembelajaran Inquiry sebesar 38,9476 \% termasuk ke dalam kategori tidak efektif.

Berdasarkan hasil penelitian ini, disarankan bagi guru dan pendidik untuk senantiasa menyelenggarakan kegiatan pembelajaran dengan model pembelajaran yang menyenangkan dan disesuaikan dengan kehidupan siswa serta karakter yang dimiliki siswa, terutama pada mata pelajaran matematika agar pembelajaran bermakna bagi siswa. Dengan penyesuaian tersebut, memberi peluang terhadap tercapainya tujuan pembelajaran dengan baik. Sehingga matematika tidak akan lagi menjadi hal yang sulit dan ditakuti siswa.

\section{Daftar Rujukan}

Arends, R.I. (2012). Learning to Teach. New York: McGraw-Hill Companies, Inc.

Ariyana, dkk. (2018). Buku Pegangan Pembelajaran Berorientasi pada Keterampilan Berpikir Tingkat Tinggi. Direktorat Jenderal Guru dan Tenaga Kependidikan Kementerian Pendidikan dan Kebudayaan.

Astuti, D.A.P., Slameto, S., \& Setyaningtyas, E. W. (2018). Pengaruh Model Pembelajaran Problem Based Learning Terhadap Kemampuan Pemecahan Masalah Matematika Siswa Sekolah Dasar. JS (JURNAL SEKOLAH), 2(2), 102-109.

Daryanto \& Karim, Syaiful. (2017). Pembelajaran Abad 21. Yogyakarta: Penerbit Gava Media.

Indarwati, D., Wahyudi W., \& Ratu, N. (2014). Peningkatan Kemampuan Pemecahan Masalah Matematika Melalui Penerapan Problem Based Learning Untuk Siswa Kelas V SD. Satya Widya, 30(1), 17-27

Karso, dkk. (2014). Pendidikan Matematika I. Tangerang Selatan: Universitas Terbuka.

Komalasari, M.D. (2011). Meningkatkan Pemahaman Konsep Penjumlahan dan Pengurangan pada Pecahan melalui Penerapan Teori Belajar Bruner pada Siswa Kelas IVB Sekolah Dasar Negeri Keputran A. Yogyakarta. Skripsi. UNY. 
Nadhifah, G., \& Afriansyah, E.A. (2016). Peningkatan Kemampuan Pemecahan Masalah Matematis Siswa dengan Menerapkan Model Pembelajaran Problem Based Learning dan Inquiry. Mosharafa : Jurnal Pendidikan Matematika, 5(1), 33-44.

Maarif, Hanafi \& Wahyudi. (2015). Eksperimentasi Problem Based Learning dan CIRC dalam Menyelesaikan Soal Cerita Matematika Kelas 5 SD. Scholaria.5 (2): 97-115.

Peraturan Menteri Pendidikan dan Kebudayaan Nomor 21 Tahun 2016 tentang Standar Isi.

Peraturan Menteri Pendidikan dan Kebudayaan Nomor 22 Tahun 2016 tentang Standar Proses Pendidikan Dasar dan Menengah.

Slameto. (2012). Penelitian dan Inovasi Pendidikan. Salatiga : Widya Sari Press Salatiga.

Sugiyono. (2012). Metode Penelitian Kuantitatif, Kualitatif, dan R\&D. Bandung: Alfabeta.

Sugiyono. (2015). Metode Penelitian Kuantitatif, Kualitatif, dan R\&D. Bandung: Alfabeta.

Trianto. (2009). Mendesain Model Pembelajaran Inovatif - Berorientasi Kontruktivistik. Jakarta: Prestasi Pustaka.

Wahyudi, I., \& Anugraheni, I. (2017). Strategi Pemecahan Masalah Matematika. Salatiga: Widya Sari Press.

Wardani, N.S., \& Slameto, A.W. (2012). Asesmen Pembelajaran SD. Salatiga: Widya Sari Press Salatiga.

Litbang Kemendikbud. (2016). Kurikulum 2013: Pergeseran Paradigma Belajar Abad 21 (0nline). http://litbang.kemendikbud.go.id /index.php.index-berita-kurikulum/234-kurikulum2013-pergeseran-paradigma-belajar-abad-21, diakses pada 11 November. 